\title{
Gender Differences in Heart Failure: Findings from Italian Internal Medicine Wards
}

\author{
Paolo Biagi ${ }^{1, ~ *, ~ V a l e r i o ~ V e r d i a n i ~}{ }^{2}$, Niccolo' Napoli ${ }^{3}$, Cristiana Seravalle ${ }^{4}$, Luca Masotti ${ }^{4}$, Irene Chiti ${ }^{5}$, \\ Grazia Panigada ${ }^{5}$
}

${ }^{1}$ Medicina Interna Ospedale di Montepulciano, Montepulciano (SI), Italy

${ }^{2}$ Medicina Interna Ospedale della Misericordia, Grosseto, Italy

${ }^{3}$ Scuola di Specializzazione Chirurgia Generale Universitaria di Pisa, Pisa, Italy

${ }^{4}$ Medicina Interna Ospedale S Maria Nuova, Firenze, Italy

${ }^{5}$ Medicina Interna Ospedale SS Cosma e Damiano di Pescia, Pescia (PT), Italy

Email address:

chipama@libero.it (P. Biagi)

\section{To cite this article:}

Paolo Biagi, Valerio Verdiani, Niccolo' Napoli, Cristiana Seravalle, Luca Masotti, Irene Chiti, Grazia Panigada. Gender Differences in Heart Failure: Findings from Italian Internal Medicine Wards. American Journal of Internal Medicine. Vol. 3, No. 2, 2015, pp. 55-66.

doi: 10.11648/j.ajim.20150302.13

\begin{abstract}
Background and aim: Literature evidence shows that about one half of patients with heart failure (HF) are females. However, they are poorly represented in clinical trials. Therefore, this syndrome remains still understood and its burden underestimated in female sex. The aim of our study was to compare demography, etiology, clinical patterns, outcome, comorbidity, disability and cognitive performance between females and males in a cohort of patients with HF. Materials and methods: We analyzed data of the Confine Study, a recently real world survey performed in Italian Internal Medicine wards. We compared clinical and instrumental characteristics between males and females. Results: Females with HF were significantly older than men. Hypertensive and valvular etiologies were significantly more prevalent in females whereas ischemic and dilatative were in males. Neither clinical aspects, with the exception of atrial fibrillation, nor echocardiographic aspects were more frequent in females. According to international guidelines on topic, both sexes received under-treatment, but this one was more evident in females. Females presented more frequently cognitive impairment and functional disability than males. Conclusion: Female sex is under-represented in clinical trials on HF. Our study may provide a contribute on this topic.
\end{abstract}

Keywords: Heart Failure, Gender, Therapy, Symptoms, Diagnosis, Epidemiology, Internal Medicine

\section{Introduction}

Heart failure (HF) prevalence increased steadily over the last decades. Aging population, advancements in the treatment of coronary heart disease and intensive control of blood hypertension proved a consequent rise in the number of hospital admissions for HF exacerbations.

Large population-based studies identify key sex-based differences in HF incidence and prevalence. In the Framingham Heart HF incidence increased by approximately $5 \%$ in women in the 1990s compared with the 1970s (1). In the Olmsted County Study, no significant increase in HF incidence was seen in men but a significant $10 \%$ increase in women since 1979 (2). Despite the overall incidence of HF remains approximately $25 \%$ lower in women compared with men, women account for $50-55 \%$ of the prevalent HF cases because of their greater life expectancy. Therefore, women represent a growing proportion of the heart failure epidemic. Around $35 \%$ of cardiovascular (CVD) mortality in women is due to HF (3). However, women are yet understudied and represented in clinical trials, sometimes inadequately powered to detect a benefit of HF therapy. So, HF remains a poorly recognized and poorly understood syndrome in women $(4,5)$.

Literature evidence shows that women with HF are more likely to be older, hypertensive, have less ischemic heart disease and may have more preserved systolic function when compared with their male counterparts $(6,7)$. However, literature lacks on HF in women in the "real world". Previous studies have shown that the patients admitted in Internal Medicine ( IM ) wards are strictly similar to that of the real world. In fact, in this setting the patients are older, 
have multiple co-morbidity and the majority of them are women (8). Therefore, the aim of our study was to analyse gender related differences in $\mathrm{HF}$ with respect to the demographics, underlying etiology, outcome, prevalence of co-morbidity, functional disability and cognitive performance status in Internal Medicine wards.

\section{Materials and Methods}

The CONFINE Study (Comorbidities and Outcome iN patients with chronic heart Failure: a study in InterNal mEdicine units in Italy) is an observational, multicenters study performed in 91 Internal Medicine wards representative of the Italian setting and associated to the Scientific Society FADOI (Italian Federation of the Associations of Hospital Internists). General results of the CONFINE Study were previously published (9).

The patient were recruited according to a spot analysis method as elsewhere stated (9). All patients with HF according to the European Society of Cardiology (ESC) guidelines (10) admitted or already present in the ward in the index day where enrolled in the study, without any exclusion criteria.

The patients were divided by gender and the following data relative to index day, day of hospitalization and day of discharge were collected: age, gender, blood pressure, heart rate, NYHA class, body mass index (BMI), 12-leads ECG records, etiology of heart failure, co-morbidities (see below), laboratory findings, pharmacological treatment with particular reference to cardiovascular therapy.

Trans-thoracic echocardiogram was performed only in some selected centers according to instrument availability.

The following comorbidities were systematically recorded:

- chronic obstructive pulmonary disease (COPD): defined on the clinical ground or specific therapy

- diabetes: defined as previous diagnosis, or specific therapy, or blood glucose greater than $126 \mathrm{mg} / \mathrm{dl}$

- blood hypertension: defined according to the Guidelines issued by International Society of Hypertension (ISH)ESC (11) or specific therapy.

- anemia: defined according to the World Health Organization (WHO) definition (12)

- renal failure: glomerular filtration rate (GFR) was calculated according to the Cockroft-Gault formula

- chronic inflammatory diseases (e.g. Rheumatoid arthritis, systemic lupus erythematous, ulcerative colitis, Crohn disease)

- cognitive impairment/dementia: evaluated on the basis of the Pfeiffer test (13)
- cerebrovascular disease: patient's history of stroke or transient ischemic attack

Functional disability was evaluated by the Barthel Index (14); quality of life was assessed by administering the Minnesota Living with Heart Failure (MLWHF) Questionnaire (15).

Poor outcome was defined as in hospital all cause mortality or worsening of clinical conditions that required transfer to Intensive Care Unit.

\section{Ethical Approval}

The study was approved by the local ethic committees of the Centers participating to the CONFINE Study. Written informed consent for data handling was also obtained by the patients.

\section{Statistics}

The data were analysed by calculating averages ( Mean \pm SD ) of continuous variables or percentages for notcontinuous ones. In some cases, it was applied a transformation in not-continuous variable in order to define a clinical severity (mild, moderate and severe) score. Numeric variables were compared by Student $t$ test for paired data and discrete variables were summarized by frequency percent and compared by the chi-square test to find significant differences between males and females. A p value $<0,05$ was considered statistically significant. Statistical analyses were carried out using SAS software (version 9.1, SAS Institute Cary, NC, USA ).

\section{Results}

\subsection{Patients Population}

In the CONFINE Study 1430 patients were recruited. In the whole cohort, genders were equally represented (M 48\%, F 52\%). The mean age of female was statistically higher $(80,7 \pm 8,7$ versus $76,6 \pm 10$ years, $\mathrm{p}<0.001) .56,9 \%$ of females were 80 years old or older compared with $36 \%$ of males $(p<0.001)$. Underweight and severe obesity were significantly more represented in females. Blood glucose, total cholesterol, HDL cholesterol were statistically higher in females, whereas uric acid was in males. No differences were found for the mean systolic and diastolic blood pressure and for the other laboratory parameters analyzed. The Tab.I summarizes the general characteristics of patients according to sex.

Table I. General characteristic of patients according to sex.

\begin{tabular}{llll}
\hline & Male $\mathbf{N}=\mathbf{6 9 3}$ & Female $\mathbf{N}=\mathbf{7 3 7}$ & P \\
\hline Age $($ mean \pm SD) & $76,6 \pm 10,0$ & $80,7 \pm 8,7$ & 0,001 \\
$\leq 40$ & $0,3 \%$ & $0,2 \%$ & 0,001 \\
$41-60$ & $4,4 \%$ & $1,9 \%$ & 0,001 \\
$61-70$ & $12,8 \%$ & $6,2 \%$ & 0,001 \\
$71-80$ & $35,1 \%$ & $26,5 \%$ & 0,001 \\
\hline
\end{tabular}




\begin{tabular}{|c|c|c|c|}
\hline & Male $\mathrm{N}=693$ & Female $\mathrm{N}=737$ & $\mathbf{P}$ \\
\hline $81-90$ & $29,4 \%$ & $46,2 \%$ & 0,001 \\
\hline$>90$ & $6,6 \%$ & $10,7 \%$ & 0,008 \\
\hline $\mathrm{BMI}($ mean $\pm \mathrm{SD})$ & $27,4 \pm 7,0 \quad \mathrm{~N}=555$ & $27,0 \pm 5,7 \mathrm{~N}=531$ & $\mathrm{~ns}$ \\
\hline Underweight $(\leq 18,5)$ & $1,3 \%$ & $3,7 \%$ & 0,01 \\
\hline Normal $(18,5-24,9)$ & $33,8 \%$ & $37,4 \%$ & ns \\
\hline Overweight $(25-29,9)$ & $44,8 \%$ & $33,3 \%$ & 0,001 \\
\hline Obese $(\geq 30,0)$ & $17,6 \%$ & $24,6 \%$ & 0,005 \\
\hline \multicolumn{4}{|l|}{ Vital signs } \\
\hline $\mathrm{SBP}($ mean $\pm \mathrm{SD}-\mathrm{mmHg})$ & $140,2 \pm 27,6$ & $141,6 \pm 26,0$ & ns \\
\hline $\mathrm{DBP}($ mean $\pm \mathrm{SD}-\mathrm{mmHg})$ & $81,3 \pm 13,7$ & $81,3 \pm 13,0$ & $\mathrm{~ns}$ \\
\hline Heart rate ( mean \pm SD-beats $/$ min) & $90,1 \pm 21,5$ & $91,7 \pm 21,8$ & ns \\
\hline $\mathrm{TSH}($ mean \pm SD-mU/L-n=525) & $4,3 \pm 15,9$ & $3,4 \pm 11,7$ & ns \\
\hline Creatinine $($ mean \pm SD-mg/dL $)$ & $1,48 \pm 0,9$ & $1,53 \pm 0,9$ & ns. \\
\hline BUN $($ mean \pm SD mg/dL $)$ & $64,4 \pm 49,8$ & $62,8 \pm 43,41$ & $\mathrm{~ns}$ \\
\hline Blood (glucose mean $\pm \mathrm{SD}$ mg/dL ) & $132,7 \pm 63,8628$ & $140,9 \pm 75,4687$ & 0,03 \\
\hline Total cholesterol ( mean $\pm \mathrm{SD}$ mg/Dl ) & $149,33 \pm 46,7465$ & $156,5 \pm 58,0454$ & 0,04 \\
\hline HDL cholesterol $($ mean \pm SD mg/dL $)$ & $41,3 \pm 18,8366$ & $45,3 \pm 32,7 \quad 367$ & 0,01 \\
\hline Tryglicerides ( mean $\pm \mathrm{SD} \mathrm{mg} / \mathrm{dL}$ ) & $97,6 \pm 45,2465$ & $98,42 \pm 51,3473$ & 0,8 \\
\hline Uric acid ( mean \pm SD mg/dL $)$ & $7,8 \pm 4,8$ & $7,1 \pm 2,7$ & 0,002 \\
\hline
\end{tabular}

Legend: Data are expressed by mean $\pm \mathrm{SD}$ or percentage. $\mathrm{BMI}=$ Body Mass Index; $\mathrm{SBP}=$ Systolic blood pressure; $\mathrm{DBP}=$ Diastolic blood pressure; $\mathrm{BUN}=$ Blood urea nitrogen, $\mathrm{TSH}=$ thyroid stimulating hormone; $\mathrm{HDL}=$ high density lipoprotein

\subsection{HF Characteristics}

Around $40 \%$ of men and $35 \%$ of women were admitted with a " de novo " diagnosis of HF; most of them were in NYHA Class III-IV with no differences by gender.
Hypertensive and valvular etiologies were significantly more prevalent in females, whereas ischemic and dilatative heart etiologies were significantly higher in males (see Tab. II).

Table II. HF characteristic according to sex.

\begin{tabular}{|c|c|c|c|}
\hline & Male & Female & $\mathbf{P}(\mathbf{X} 2$ Yates $)$ \\
\hline NYHA Class (\%) & Number $(N)=636$ & $\mathrm{~N}=679$ & \\
\hline I & 1,5 & 2,5 & 0.3 \\
\hline II & 16,8 & 14,8 & 0,4 \\
\hline III & 47,6 & 44,5 & 0,3 \\
\hline IV & 33,9 & 38,1 & 0,1 \\
\hline \multicolumn{4}{|l|}{ Underlying cause of heart failure (\%) } \\
\hline Hypertensive heart disease & 39 & 46,5 & 0,001 \\
\hline Ischemic heart disease & 46 & 37,5 & 0,001 \\
\hline Valvular heart disease & 15,6 & 26,0 & 0,001 \\
\hline Dilatative Heart disease & 21,9 & 14,1 & 0,002 \\
\hline Congenital heart disease & 0,2 & 0,9 & $\mathrm{~ns}$ \\
\hline Other & 12,5 & 15,4 & ns \\
\hline Risk factors for clinical deterioration (\%) & $\mathrm{N}=692$ & $\mathrm{~N}=736$ & \\
\hline Hypertension & 28,1 & 31,6 & 0,1 \\
\hline Arrhytmias & 27,6 & 29,3 & 0,5 \\
\hline Anaemia & 18,9 & 22,4 & 0,3 \\
\hline Poor compliance to therapy & 16,2 & 14,1 & 0,3 \\
\hline Thyreotoxicosis & 1,3 & 1,9 & 0,4 \\
\hline Pulmonary embolism & 0,8 & 0,1 & 0,7 \\
\hline Signs and symptoms (\%) & $\mathrm{N}=688$ & $\mathrm{~N}=731$ & \\
\hline Exertion dyspnea & 86,3 & 85,2 & 0,6 \\
\hline Lung crepitations & 78,9 & 78,4 & 0,9 \\
\hline Ankle edema & 71,8 & 66,5 & 0,03 \\
\hline
\end{tabular}




\begin{tabular}{llll}
\hline & Male & Female & P (X2 Yates ) \\
\hline Night cough & 51,6 & 49,6 & 0,5 \\
Neck vein distension & 53,3 & 47,8 & 0,04 \\
Hepatomegaly & 50,6 & 36,6 & 0,001 \\
Pleural effusion & 35,9 & 36,9 & 0,7 \\
Acute pulmonary edema & 23,2 & 25,6 & 0,3 \\
12-leads ECG records at hospital admission (\%) & $\mathrm{N}=680$ & $\mathrm{~N}=723$ & 0,01 \\
Sinus rhythm & 51,8 & 45,2 & 0,004 \\
Atrial fibrillation & 38,5 & 46,2 & 0,03 \\
Pacemaker rhythm & 11,9 & 8,2 & 0,01 \\
Left bundle branch block & 15,8 & 14,4 & 0,5 \\
Right bundle branch block & 14,8 & 10,5 & 0,2 \\
Left ventricular hypertrophy & 24,7 & 26,9 & $\mathrm{~N}$ \\
Echocardiography at hospital admission & $\mathrm{N}=197$ & $\mathrm{~N}=206$ & $\mathrm{n}$ \\
Left ventricle Ejection Fraction (LVEF) & $42,1 \pm 11,7$ & $44,4 \pm 12,7$ & $\mathrm{~ns}$ \\
LVEF $>50 \%$ & $35,5 \%$ & $31,5 \%$ & $20,8 \%$ \\
LVEF $<30 \%$ & $15,7 \%$ & & \\
\hline
\end{tabular}

No difference was noted for risk factors of clinical deterioration. None sign or symptom was significantly more frequent in females. The prevailing phenotype was the congestive syndrome for both sexes. At hospital admission trans-thoracic echocardiography showed an average left ventricular ejection fraction (LVEF) higher in women, but significant difference was not found for LVEF $<30 \%$ or LVEF> 50\% according to sex. Myocardial infarction was present in $4,4 \%$ in men and $5,4 \%$ in women: this difference was not statistically significant $(\mathrm{p}=0,4)$.

\subsection{Co-morbidity}

The average number of co-morbidities was significantly higher in females $(3,4$ vs 3,$2 ; p<0,01)$. Women showed significantly more prevalence of mild hypertension, severe renal failure $(\mathrm{GFR}<30 \mathrm{ml} / \mathrm{min})$, metabolic syndrome and cognitive impairment but lower prevalence of COPD. The other differences were not statistically significant (see Tab. III ).

Table III. Prevalence of co-morbidity according to sex

\begin{tabular}{|c|c|c|c|}
\hline & Male $N=690$ & Female $N=731$ & \\
\hline GFR* & $\%$ & $\%$ & $\mathrm{P}$ \\
\hline Normal & 53,4 & 58,1 & 0,05 \\
\hline $61-89$ & 16,3 & 13,8 & ns \\
\hline $31-60$ & 20,8 & 16,4 & 0,05 \\
\hline $0-30$ & 8,6 & 11,4 & 0,05 \\
\hline Dialysis & 0,5 & 0,1 & ns \\
\hline Diabetes & 32,7 & 32,6 & ns \\
\hline \multicolumn{4}{|l|}{ Hypertension } \\
\hline No & 39,1 & 35,2 & ns \\
\hline Mild & 33,3 & 35,7 & 0,01 \\
\hline Moderate & 22,1 & 23,6 & ns \\
\hline Severe & 5,3 & 5,3 & ns \\
\hline COPD & $32,8 \%$ & $21,0 \%$ & 0,001 \\
\hline Cachexia $^{\wedge}$ & $6,6 \%$ & $6,8 \%$ & ns \\
\hline Dementia & $18 \%$ & $24,7 \%$ & 0,01 \\
\hline Anemia $^{\circ}$ & $41,3 \%$ & $42,6 \%$ & ns \\
\hline Metabolic syndrome $\S$ & $45,5 \%$ & $55,5 \%$ & 0,01 \\
\hline Chronic disease $\S \S$ & $7,1 \%$ & $7,8 \%$ & ns \\
\hline
\end{tabular}

Legend: $\mathrm{GFR}=$ glomerular filtration rate; $\mathrm{COPD}=$ chronic obstructive pulmonary disease

* according to the Cockroft-Gault formula

$\wedge \mathrm{BMI}<18,5$

${ }^{\circ}$ according to the WHO criteria

$\S$ minimum 3 NCEPIII criteria to meet the diagnosis of metabolic syndrome

$\S \S$ include Rheumatoid Arthritis, Systemic Lupus erythematous, Crohn disease, Ulcerative colitis and Chronic Hepatitis or Cirrhosis 


\subsection{Treatment}

The prevalence of cardiovascular therapy at the hospital admission and discharge is reported in Tab. IV. The dose of each pharmacological class was impossible to report from the data sheets. At hospital discharge ACE inhibitors and/or ARBS, beta blockers and anti-aldosterone agents were more prescribed compared with hospital admission for both sexes. Females were significantly more treated with digoxin and less with aspirin than their male counterpart at hospital discharge. None significant difference was registered in the intravenous administration of diuretics (furosemide), nitrates, inhotropic agents such as dobutamine and antiarrhythmics such as amiodarone at hospital admission for acute or decompensated HF ( Tab. V). In the subgroup of patients with atrial fibrillation $(\mathrm{N}=601,42 \%)$, the prescription of aspirin (ASA) and vitamin $\mathrm{K}$ antagonists (VKAs) increased at hospital discharge. However, none statistically significant difference between sexes was found (Tab. VI).

Table IV. Use of cardiovascular drugs according to sex.

\begin{tabular}{lllllll}
\hline & \multicolumn{2}{l}{ Hospital admission (\%) } & \multicolumn{3}{l}{ Hospital discharge (\%) } \\
& Male N=672 & Female $\mathbf{N = 7 1 5}$ & $\mathbf{P}$ & Male N=581 & Female N=640 & P \\
\hline ACE-inhibitors & 52,6 & 51,2 & 0,59 & 47,3 & 45,6 & 0,55 \\
Allopurinol & 18,7 & 13,7 & 0,05 & 24,9 & 20,3 & 0,05 \\
ARBs & 13 & 16 & 0,13 & 32,1 & 32,2 & 0,9 \\
Aspirin & 37,6 & 31,2 & 0,001 & 42,6 & 33,4 & 0,001 \\
Beta blockers & 23,6 & 23,7 & 0,9 & 31,6 & 30,4 & 0,6 \\
Calcium-channel blockers & 12 & 15,8 & 0,05 & 13,7 & 15,4 & 0,4 \\
Digoxin & 26 & 30,3 & 0,1 & 25,4 & 37,2 & 0,001 \\
Furosemide (oral ) & 47,3 & 45,6 & 0,53 & 80,3 & 81,6 & 0,6 \\
Anti-aldosterone agents & 21 & 20,6 & 0,9 & 29,5 & 34,5 & 0,05 \\
Warfarin & 22,4 & 23,6 & $\mathrm{~ns}$ & 24,7 & 25,6 & $\mathrm{~ns}$ \\
\hline
\end{tabular}

*N=number of data sheets available; for 14 subjects gender was not reported

Table V. Intravenous pharmacological treatment according to sex at hospital admission

\begin{tabular}{|c|c|c|c|}
\hline Drugs by i.v.route at hospital admission (\%) & Males $(\mathrm{N}=652)$ & Females $(N=699)$ & $p\left(X^{2}\right)$ test \\
\hline Diuretics & 61,8 & 63,6 & 0,51 \\
\hline Nitrates & 17,3 & 16,3 & 0,09 \\
\hline Dobutamine & 1,5 & 0,7 & 0,2 \\
\hline Amiodarone & 3,9 & 2,5 & 0,2 \\
\hline
\end{tabular}

Table VI. Antithrombotic treatment in patients with atrial fibrillation and heart failure according to sex

\begin{tabular}{|c|c|c|c|c|c|c|}
\hline & \multicolumn{3}{|c|}{ Hospital admission } & \multicolumn{3}{|c|}{ Hospital discharge } \\
\hline & $\mathbf{M}$ & $\mathbf{F}$ & $P\left(X^{2}\right.$ test & $\mathbf{M}$ & $\mathbf{F}$ & $P\left(X^{2}\right.$ test \\
\hline $\begin{array}{l}\text { Vitamin } K \\
\text { anatagonists (\%) }\end{array}$ & 36,3 & 40,0 & 0,4 & 43,2 & 42,0 & 0,9 \\
\hline $\begin{array}{l}\text { Antiplatelet drugs } \\
(\%)\end{array}$ & 28,4 & 26,6 & 0,68 & 35 & 31,5 & 0,67 \\
\hline
\end{tabular}

\subsection{Functional Status and Quality of Life}

Barthel Index Score (BIS) was tested at index day and at hospital discharge to ascertain whether hospitalization may impair self autonomy. A severely impaired functional status (BIS $\leq 30$ ) was registered in $17,6 \%$ of males and in $27,6 \%$ of females $(p<0,01)$. For each activity performing BIS the average score was higher in men than in women both at the index day and at the discharge, which means that females have less self autonomy for each activity. Females showed a remarkable higher prevalence of permanent bed rest $(12,3 \%$ vs $17,4 \%)$ and urinary incontinence $(12,0 \%$ vs $18,2 \%)$ than males. In hospital staying worsened significantly disability in both sexes.

The average score in the Minnesota Living with Heart Failure Questionnaire was similar in both sexes ( $\mathrm{M}=58,5 \pm$ $35,8$ vs $60,5 \pm 31,9, \mathrm{~ns})$. Only the answers to the questions $\mathrm{n}^{\circ}$ 10 (Making your sexual activities more difficult?) and $\mathrm{n}^{\circ} 21$ (Making you feel depressed ?) showed a statistically significant difference between sexes $(\mathrm{p}<=0,01)$. Both for men and women the most troublesome concerns with HF were hospitalization (more than 60\%), shortness of breath (more than 55\%) and loss of energy (53-56\%) (See Tab. VIII). 
Table VII. The Barthel Index distribution according to sex

\begin{tabular}{|c|c|c|c|c|c|c|}
\hline & Male & & & Female & & \\
\hline & Index day $\mathrm{N}=512$ & Discharge $N=461$ & $\mathbf{P}$ & Index day $\mathrm{N}=559$ & Discharge $N=515$ & $\mathbf{P}$ \\
\hline Barthel Index Score & $64,7 \pm 30,7$ & $72,21 \pm 28,8$ & 0,001 & $53,9 \pm 31,4$ & $61,46 \pm 31,7$ & 0,001 \\
\hline \multicolumn{7}{|l|}{ Activity } \\
\hline Feeling ( $0-10)$ & $7,9 \pm 2,9$ & $8,4 \pm 2,8$ & 0,005 & $6,9 \pm 3,4$ & $7,5 \pm 3,2$ & 0,005 \\
\hline Bathing (0-5) & $2,5 \pm 2,5$ & $2,8 \pm 2,5$ & 0,01 & $1,7 \pm 2,4$ & $2,1 \pm 2,5$ & 0,001 \\
\hline Grooming $(0-5)$ & $3,1 \pm 2,4$ & $3,4 \pm 2,3$ & 0,01 & $2,5 \pm 2,5$ & $3,0 \pm 2,4$ & 0,001 \\
\hline Dressing $(0-10)$ & $5,8 \pm 3,7$ & $6,5 \pm 3,6$ & 0,005 & $4,6 \pm 3,7$ & $5,4 \pm 3,7$ & 0,001 \\
\hline Bowels (0-10) & $8,3 \pm 3,1$ & $8,4 \pm 3,0$ & ns & $7,4 \pm 3,6$ & $7,7 \pm 3,5$ & ns \\
\hline Bladder $(0-10)$ & $7,5 \pm 3,5$ & $7,7 \pm 3,6$ & ns & $6,4 \pm 4,1$ & $7,0 \pm 4,0$ & 0,05 \\
\hline Toilet use (0-10) & $6,1 \pm 4,0$ & $6,8 \pm 3,9$ & 0,001 & $4,6 \pm 3,9$ & $5,6 \pm 3,9$ & 0,001 \\
\hline $\begin{array}{l}\text { Transfer ( bed to chair and } \\
\text { back ) }(0-15)\end{array}$ & $9,1 \pm 5,3$ & $10,4+5,0$ & 0,001 & $7,5 \pm 5,2$ & $8,7 \pm 5,3$ & 0,001 \\
\hline $\begin{array}{l}\text { Mobility ( on level surfaces ) } \\
(0-15)\end{array}$ & $9,8 \pm 5,3$ & $10,9+5,0$ & 0,001 & $8,0 \pm 5,6$ & $9,1 \pm 5,5$ & 0,001 \\
\hline Stairs $(0-10)$ & $5,0 \pm 4,0$ & $5,9 \pm 3,9$ & 0,001 & $3,8 \pm 3,8$ & $4,7 \pm 3,9$ & 0,001 \\
\hline
\end{tabular}

Legend: in brackets the score grading for each item ( total 0-100). Total score and every activity ( mean $\pm \mathrm{SD}$ ) were compared with values of index day. $\mathrm{N}=$ number of data sheets recorded

Table VIII. The Minnesota Living with Heart Failure Questionnaire distribution according to sex.

\begin{tabular}{|c|c|c|c|c|c|c|c|c|c|}
\hline \multirow{3}{*}{\multicolumn{2}{|c|}{$\begin{array}{l}\text { Did your HF prevented you from } \\
\text { living as you wanted during the } \\
\text { last two months }\end{array}$}} & \multicolumn{6}{|c|}{ SCORE } & & \\
\hline & & \multirow{2}{*}{$\begin{array}{l}\text { Mean } \pm S D \\
M\end{array}$} & \multirow{2}{*}{$\begin{array}{l}\text { Mean } \pm \text { SD } \\
\text { F }\end{array}$} & \multicolumn{2}{|c|}{$0-1(\%)$} & \multicolumn{2}{|c|}{$2-3(\%)$} & \multicolumn{2}{|c|}{$4-5(\%)$} \\
\hline & & & & M & $\mathbf{F}$ & M & $\mathbf{F}$ & $\mathbf{M}$ & $\mathbf{F}$ \\
\hline 1 & $\begin{array}{l}\text { Causing swelling in your } \\
\text { ankles, legs? }\end{array}$ & $2,5 \pm 1,6$ & $2,5 \pm 1,7$ & 28,1 & 29,6 & 41,8 & 41,2 & 30 & 29,1 \\
\hline 2 & $\begin{array}{l}\text { Making you sit or lie down } \\
\text { to rest during the day? }\end{array}$ & $2,9 \pm 1,4$ & $2,9 \pm 1,5$ & 16,9 & 17,6 & 43,5 & 42,1 & 39,5 & 40,2 \\
\hline 3 & $\begin{array}{l}\text { Making you walking about } \\
\text { or climbing stairs difficult? }\end{array}$ & $3,4 \pm 1,5$ & $3,4 \pm 1,6$ & 12 & 13,6 & 34,4 & 29,6 & 49,2 & 56,3 \\
\hline 4 & $\begin{array}{l}\text { Making your working } \\
\text { around the house yard } \\
\text { difficult? }\end{array}$ & $3,1 \pm 1,6$ & $3,3 \pm 1,6$ & 17,7 & 15,5 & 34,6 & 30,8 & 47,5 & 53,6 \\
\hline 5 & $\begin{array}{l}\text { Making your going places } \\
\text { away from home difficult? }\end{array}$ & $2,9 \pm 1,8$ & $3,0 \pm 1,8$ & 25,3 & 21,8 & 31,2 & 30,3 & 41,2 & 47,9 \\
\hline 6 & $\begin{array}{l}\text { Making your sleeping well } \\
\text { at night difficult? }\end{array}$ & $2,9 \pm 1,5$ & $3,1 \pm 1,5$ & 19,8 & 17,6 & 38,9 & 37,3 & 41,2 & 45,1 \\
\hline 7 & $\begin{array}{l}\text { Making your sleeping to or } \\
\text { doing things with your } \\
\text { friend or family difficult? }\end{array}$ & $2,6 \pm 1,7$ & $2,6 \pm 1,7$ & 26,4 & 27,2 & 39,5 & 36 & 33,4 & 36,7 \\
\hline 8 & $\begin{array}{l}\text { Making your working to } \\
\text { earn a living difficult? }\end{array}$ & $1,8 \pm 1,8$ & $2,0 \pm 1,9$ & 50,3 & 46,9 & 25,1 & 23,1 & 24,5 & 29,8 \\
\hline 9 & $\begin{array}{l}\text { Making your recreational } \\
\text { past times, sports or hobbies } \\
\text { difficult? }\end{array}$ & $2,3 \pm 1,7$ & $2,4 \pm 1,8$ & 36,6 & 35,4 & 32,9 & 31,2 & 30 & 14,2 \\
\hline 10 & $\begin{array}{l}\text { Making your sexual } \\
\text { activities more difficult? }\end{array}$ & $1,9 \pm 2,1$ & $1,5 \pm 2,1$ & 55.7 & 64,5 & 13,7 & 10,5 & 30,6 & 24,9 \\
\hline 11 & $\begin{array}{l}\text { Making you eat less of the } \\
\text { foods you like? }\end{array}$ & $2,2 \pm 1,6$ & $2,4 \pm 1,6$ & 33,8 & 30,6 & 42,7 & 43,6 & 23,4 & 25,6 \\
\hline 12 & Making you short of breath? & $3,5 \pm 1,4$ & $3,5 \pm 1,4$ & 9,3 & 11,6 & 34,6 & 20,2 & 56 & 58 \\
\hline 13 & $\begin{array}{l}\text { Making you tired, fatigued } \\
\text { or low on energy? }\end{array}$ & $3,4 \pm 1,4$ & $3,4 \pm 1,5$ & 10,7 & 13,2 & 34,8 & 29,8 & 53,9 & 56,8 \\
\hline 14 & Making you stay in a & $3,5 \pm 1,0$ & $3,6 \pm 1,5$ & 11,6 & 12,2 & 26,4 & 20,1 & 61,5 & 63,7 \\
\hline
\end{tabular}




\begin{tabular}{|c|c|c|c|c|c|c|c|c|c|}
\hline \multirow{3}{*}{\multicolumn{2}{|c|}{$\begin{array}{l}\text { Did your HF prevented you from } \\
\text { living as you wanted during the } \\
\text { last two months }\end{array}$}} & \multirow{3}{*}{$\begin{array}{l}\text { Mean } \pm \text { SD } \\
M\end{array}$} & \multirow{3}{*}{$\begin{array}{l}\text { Mean } \pm \text { SD } \\
\text { F }\end{array}$} & \multicolumn{4}{|c|}{ SCORE } & \multirow{2}{*}{\multicolumn{2}{|c|}{$4-5(\%)$}} \\
\hline & & & & \multicolumn{2}{|c|}{$0-1(\%)$} & \multicolumn{2}{|c|}{$2-3(\%)$} & & \\
\hline & & & & M & $\mathbf{F}$ & M & $\mathbf{F}$ & M & $\mathbf{F}$ \\
\hline & \multicolumn{9}{|l|}{ hospital ? } \\
\hline 15 & $\begin{array}{l}\text { Costing you money for } \\
\text { medical care? }\end{array}$ & $3,5 \pm 1,7$ & $3,6 \pm 1,8$ & 46,7 & 44,8 & 32,3 & 30,1 & 20,9 & 25,1 \\
\hline 16 & $\begin{array}{l}\text { Giving you side effects from } \\
\text { medications? }\end{array}$ & $1,6 \pm 1,5$ & $1,6 \pm 1,6$ & 50,7 & 50,3 & 35,3 & 34,3 & 12,6 & 13,4 \\
\hline 17 & $\begin{array}{l}\text { Making you feel you are a } \\
\text { burden to your family or } \\
\text { friends? }\end{array}$ & $2,2 \pm 1,6$ & $2,4 \pm 1,8$ & 38,2 & 35,4 & 34 & 29,8 & 27,6 & 34,6 \\
\hline 18 & $\begin{array}{l}\text { Making you feel a loss of } \\
\text { self-control in your life? }\end{array}$ & $2,4 \pm 1,0$ & $2,5 \pm 1,7$ & 32,1 & 30,8 & 37,6 & 34,8 & 30,2 & 34,3 \\
\hline 18 & $\begin{array}{l}\text { Making you feel a loss of } \\
\text { self-control in your life? }\end{array}$ & $2,4 \pm 1,0$ & $2,5 \pm 1,7$ & 32,1 & 30,8 & 37,6 & 34,8 & 30,2 & 34,3 \\
\hline 19 & Making you worry? & $2,7 \pm 1,6$ & $3,0 \pm 1,6$ & 23,2 & 20,1 & 35,9 & 34,3 & 40,8 & 45,6 \\
\hline 20 & $\begin{array}{l}\text { Making it difficult for you } \\
\text { to concentrate or remember } \\
\text { things? }\end{array}$ & $2,4 \pm 1,6$ & $2,6 \pm 1,7$ & 33,1 & 28,9 & 35 & 36 & 31,7 & 35 \\
\hline 21 & $\begin{array}{lll}\text { Making } & \text { you } & \text { feel } \\
\text { depressed ? } & & \end{array}$ & $2,4 \pm 1,6$ & $2,7 \pm 1,7$ & 32,7 & 27,2 & 49,8 & 35,4 & 27,9 & 36,5 \\
\hline
\end{tabular}

Legend: $\mathrm{M}=$ Male; F=Female. Mean \pm SD for each single item with score percentage are reported. Males number=476, Females number=528.

\subsection{Cognitive Deficit/Dementia}

The Short portable mental status questionnaire (Pfeiffer test) corrected by education was performed in 1021 subjects; data at the index day and at the discharge are reported in Tab. IX. We found a higher severe to moderate cognitive defect
(8-10 versus 5-7 scores) in females compared to males at the index day and hospital discharge. Hospitalization worsened cognitive ability and remarkably increased the cognitive impairment at hospital discharge in both sexes.

Table IX. Pfeiffer test distribution according to sex

\begin{tabular}{|c|c|c|c|c|c|c|}
\hline & \multicolumn{3}{|l|}{ Male $N=478$} & \multicolumn{3}{|c|}{ Female $N=533$} \\
\hline & Index day & Discharge & $\mathbf{P}$ & Index day & Discharge & $\mathbf{P}$ \\
\hline Pfeiffer test (mean $\pm \mathrm{SD})$ & $2,57 \pm 3,07$ & $2,15 \pm 3,12$ & 0,05 & $3,46 \pm 3,42$ & $2,96 \pm 3,34$ & 0,05 \\
\hline $0-2(\%)$ - normal & 58,6 & 66,6 & 0,08 & 47,8 & 54,7 & 0,04 \\
\hline 3- $4(\%)$ - mild & 14,9 & 12,3 & 0,22 & 16 & 14,5 & 0,59 \\
\hline $5-7(\%)$ - moderate & 16,2 & 12,3 & 0,04 & 20,9 & 17,9 & 0,28 \\
\hline $8-10(\%)$ - severe & 9,2 & 8,8 & 0,89 & 15,2 & 9,2 & 0,27 \\
\hline
\end{tabular}

Legend: $\mathrm{N}=$ number of patients

Table X. NYHA Class at hospital discharge

\begin{tabular}{llll}
\hline NYHA (\%) & Males & Females & P (X2 test $)$ \\
\hline I & 12,6 & 9,7 & 0,1 \\
II & 58,4 & 58,1 & 0,9 \\
III & 21,5 & 25,2 & 0,09 \\
IV & 7,4 & 6,2 & 0,3 \\
\hline
\end{tabular}

\subsection{Outcome}

Mean length of hospital stay was similar in both sexes. None significant difference was noticed between sex in NYHA class at hospital discharge. NYHA improved during hospitalization, classes I-II rising from less than $20 \%$ at hospital admission to around $70 \%$ at hospital discharge (Tab. $\mathrm{X}$ ). In hospital mortality was $4,4 \%$ (60 patients, 24 males and
36 females, $\mathrm{p}=\mathrm{ns})$.

\section{Discussion}

HF is a worldwide epidemic health problem, burdening for a high percentage of resources of healthcare systems. Therefore, the knowledge of characteristics of patients with $\mathrm{HF}$ is of utmost importance. Our study provide information about HF in patients admitted in Italian Internal Medicine 
wards. Our study demonstrates that HF population admitted in Internal Medicine wards is extremely old, mean age being around 80 years. Females result significantly older than males. The distribution of age by using deciles underlines that female sex prevails in the extreme age of life: in fact more than $10 \%$ are 90 years old and older.

In our population, arterial blood hypertension represent the most prevalent HF etiology in females, confirming the results of a pooled analysis of five large clinical trials which demonstrated that $60 \%$ of females versus $43 \%$ of males with HF had non ischemic etiology (16). To now, arterial blood hypertension has a great population-attributable cardiovascular risk percentage in both sexes, and it is associated with more incident HF in females (17). It has been demonstrated that arterial blood hypertension increases the risk of HF by threefold in females compared to twofold in males (18).

It has been demonstrated that females with HF are more symptomatic at presentation $(16,19)$. In our study, despite we found that congestive syndrome represents the most prevalent phenotype, we did not find difference in clinical presentation between sexes.

HF with preserved LVEF is reported to represent the most frequent HF pattern in females (20-22). We confirmed this finding, however it should be remarked that our cohort of patients is older compared to those previously reported and quite similar to those of other surveys in identical settings in Italy $(8,23)$. The advanced age of our cohort may blunt the gender differences of LVEF reported in the literature.

Isolate $\mathrm{HF}$ was found to be present only in less than $10 \%$ of our cohort. In fact, both sexes showed at least one or two co-morbidities. A lot of co-morbidities should be taken in special consideration due to their severe burden on $\mathrm{HF}$ outcome. Chronic kidney disease (CKD) is common in $\mathrm{HF}$ failure, and shares many risk factors with $\mathrm{HF}$ such as age, arterial blood hypertension, diabetes, and coronary artery disease. Over one half of all HF patients may have moderate to severe CKD. A reduction of glomerular filtration goes on pari-passu the growing age of population and this is more evident in females (24). A study of about 120,000 contemporary acute hospitalized HF patients from the ADHERE registry indicates that CKD, defined as GFR $<60$ $\mathrm{ml} / \mathrm{min} / 1.73 \mathrm{~m}^{2}$, was present in $64 \%$ of patients. Remarkably, in this study $44 \%, 13 \%$ and $7 \%$ of patients had stage 3,4 and 5 CKD, respectively (24). Mean age of patients and impaired renal function were strictly related. Most HF patients with CKD were females $(54 \%, 58 \%$ and $54 \%$ respectively for stage 3, 4 and 5), while the majority of patients with stage 1 and 2 kidney function were males $(57 \%$ and 53, respectively)(24). Our study confirmed these findings, demonstrating a higher prevalence of mild renal failure in males compared with females who presented a higher percentage of moderate (stage 3 ).

In our study, COPD is less represented in females as elsewhere reported (25).

No gender differences in the prevalence of diabetes, regardless of the HF etiology has been reported; the prevalence ranged between 10 and $35 \%$, with higher percentages recorded in the studies enrolling patients with worse HF $(26,27)$. The prevalence of diabetes is near $10 \%$ higher in females with ischemic etiology of HF, while there was no difference in prevalence among females without ischemic HF when compared with males (16), our findings being in agreement with the abovementioned results.

Even if in absence of diabetes, obesity is a risk factor for HF. It has been estimated that the population-attributable risk percentage of HF due to overweight was $14 \%$ in females and $9 \%$ in males, while the corresponding percentages due to obesity were $14 \%$ in females and $11 \%$ in males (28). Metabolic syndrome too may play a role in favouring $\mathrm{HF}$ (29-32). This was confirmed in our study where BMI > 30 and metabolic syndrome prevailed in females, as previously demonstrated (33).

National Heart Failure Project and the Registry to Improve the Use of Evidence-Based Heart Failure Therapies in the Outpatient Setting (IMPROVE-HF) trials found that older females with HF were less likely to receive guidelinerecommended treatments compared with males (34). Females seem to be less likely to receive $\beta$-blockers than males as confirmed by CHARM study (35-36). Moreover, despite the relatively small number of females participating in each study, pooled data from the MERIT-HF, CIBIS-II and COPERNICUS trials yielded a mortality benefit with $\beta$ blockers in females similar to that recorded in males (37-39).

Our study confirms that beta blockers are still underused in clinical practice, however in our population none difference in beta blockers prescription was noted. In our study advanced age and co-morbidity seem to influence the beta blockers prescription more than gender.

Females seem to receive less ACE inhibitors than males (35). Nevertheless ACE inhibitors have shown to confer benefit on survival to males with HF and reduced LVE, to date strong literature evidence has not available for females, being demonstrated a not significant $15 \%$ reduction in all cause mortality by using ACE-inhibitors in females (40). A 12 years follow up of SOLV trial found a not significant survival benefit for females who were randomized to enalapril (41). A meta-analysis of major clinical trials concluded that only females with symptomatic LV systolic dysfunction may benefit by the use of ACE inhibitors, whereas females without symptomatic LV systolic dysfunction may have no benefits (42). Head-to-head comparisons of losartan and captopril in elderly patients with LVEF less than $40 \%$ found no benefit of losartan over captopril, an effect that was similar according to gender (43). More recently, a population based study confirmed that no difference was evident in the effectiveness of angiotensin receptor-blockers and angiotensin converting enzyme inhibitors in patients with congestive HF, however females treated by using ARS seemed to have better outcome than those on ACE inhibitors (44).

Overall, treatment by using RAAS inhibitors, with exception of spironolactone, was prescribed in both genders 
in around $75 \%$ of our patients, showing a significant increasing from hospital admission to hospital discharge. Instead, treatment by using spironolactone increased at hospital discharge only in females.

It has been demonstrated that digoxin seem to have none effect on mortality and decreased hospitalizations for HF (45). In females treated by using digoxin, it has been demonstrated a significant increased risk for all-cause mortality and a trend toward more hospital admissions (46). A post hoc analyses of our data showed that females had a higher serum digoxin concentration raising the hypothesis that this may contribute to the increased mortality among females (47).

In our study, digoxin was prescribed much more as expected according to the most recent guidelines. It was prescribed significantly more in females than in males at the hospital discharge and this finding may be explained only in part related to a higher prevalence of atrial fibrillation in females. This finding should be taken in account from internists caring patients with HF.

Although a retrospective analysis of the SOLVD trial showed that females with HF had an increased risk of thromboembolic events compared with males, cardioembolic prevention by using anticoagulants or antiplatet drugs seem to be prescribed less than males (48). Our study seems to confirm literature evidence: despite prescription of vitamin $\mathrm{K}$ antagonists and antiplatelet drugs increased from admission to hospital discharge, it remains underused (49).

$\mathrm{HF}$ is a troublesome syndrome, burdening on quality of life much more than other chronic diseases, such as arthritis and COPD (50). Impairment seems to be mainly related to intolerance to exercise, distress proved by symptoms, impaired role functioning in marital and family relationships, diminished job functioning, and reduced social support. (5153). Females have significantly worse general life satisfaction, physical function, and social and general health scores than males but none difference in current life situation or emotional distress (54).

In our study we have registered that both males and females with HF show a poor quality of life and confirmed that females feel more depressed than males and fear for loss of energy to work, walk, climb and they have growing feeling to be a burden for the family. We found that the scoring in Minnesota Living with Heart Failure Questionnaire was higher than that elsewhere reported in NYHA class I-III (55-57). It could be due to high prevalence of patients in NYHA Class III-IV at hospital admission owing the acute worsening of HF. Therefore, it is not surprising that the most troublesome problem for these patients, irrespective of gender, was the fear to be hospitalized.

In our study, functional disability worsened during hospitalization in both genders but much more in females than males. Noteworthy, severe disability (Barthel Index $<30$ ) was present in near $30 \%$ of females and $20 \%$ of males. This is a real problem for HF management, thereby we suggest that functional disability should be enclosed routinely at hospital discharge, taking into account that severe disability seems to be a powerful marker of negative outcome (9).

Cognitive performance status resulted different in females who showed more severe functional impairment compared to males and this was much more evident at hospital admission. During hospitalization Pfeiffer grading score improved in both sexes. This fact could be due to HF which per se may contribute to impair cognitive status, suggesting that an appropriate HF treatment could reduce cognitive defects, as elsewhere reported $(58,59)$.

Most epidemiological studies found that females have better survival after the onset of HF, mortality risk being approximately $15-20 \%$ less than males, but data of in hospital mortality in females lack. Much recently, in a large multicenter registry enrolling over than 50,000 patients, it was demonstrated that despite differences in baseline characteristics, females and males have similar in-hospital mortality, irrespective from LVEF (60). Our findings confirmed these data, length of hospital stay and in hospital mortality being similar in both sexes. However, it should be remarked that females were discharged more compromised, being NYHA class IV more prevalent in females at hospital discharge.

In conclusion, $\mathrm{HF}$ is a pandemic diseases burdened by high mortality, morbidity and healthcare costs. Gender medicine is emerging as one of the main sub-specialty for healthcare professionals. Our study may contribute to understanding the difference between sexes in HF.

\section{References}

[1] Levy D, Kenchaiah S, Larson MG, Benjiamin EJ, Kupka MJ, Ho KL et al. Long-term trends in the incidence of and survival with heart failure. N Engl J Med 2002; 347: 1397-1402

[2] Roger VL, Weston SA, Redfield MM, Hellermann-Homan JP, Killian J, Yawn BP et al. Trends in heart failure incidence and survival in a community-based population. JAMA 2004; 292: 344-350

[3] Rosamond W, Flegal K, Furie K. Heart disease and stroke statistics - 2008 update: a report from the American Heart Association Statistics Committee and Stroke Statistics Subcommittee. Circulation 2008;117:e25-146.

[4] Hsich, E M, Piña, I L. Heart Failure in WomenA Need for Prospective Data. J Am CollCardiol 2009; 54:491-8

[5] Shah R U , Klein L, Lloyd-Jones DM . Heart Failure in Women: Epidemiology, Biology and Treatment Women's Health. 2009; 5: 517-527.

[6] Galvao M, Kalman J, DeMarco T, Fonarow GC, Galvao C, Ghali JK et al. Gender differences in in-hospital management and outcomes in patients with decompensated heart failure: analysis from the Acute Decompensated Heart Failure National Registry (ADHERE). J Card Fail 2006;12:100 -107.

[7] Nieminen MS, Harjola VP, Hochadel M, Drexler H, Komajda $\mathrm{M}$, Brutsaert D et al. Gender related differences in patients presenting with acute heart failure. Results from EuroHeart Failure Survey II. Eur J Heart Fail 2008;10:140-148. 
[8] Di Lenarda A, Scherillo M, Maggioni AP, Acquarona N, Ambrosio GB, Annichiarico $\mathrm{M}$ et al. and TEMISTOCLE Investigators. Current presentation and management of heart failure in cardiology and internal medicine hospital units: a tale of two worlds - the TEMISTOCLE study. Am Heart J 2003;146:E12.

[9] Biagi P, Gussoni G, Iori I, Nardi R, Mathieu G, Mazzone et al. on behalf of the CONFINE Study Group. Clinical profile and predictors of in-hospital outcome in patients with heart failure: The FADOI "CONFINE" Study, Int J Cardiol 2011, doi:10.1016/j.ijcard.2011.02.025

[10] Swedberg K, Cleland J, Dargie H, Drexler H, Follath F, Komajda $\mathrm{M}$ et al. Guidelines for the diagnosis and treatment of chronic heart failure-executive summary (update 2005): The Task Force for the Diagnosis and Treatment of Chronic Heart Failure of the European Society of Cardiology. EurHeart J 2005;26:1115-40.

[11] Mancia G, de Backer G, Dominiczak A, Cifkova R, Fagar R, Germano $G$ et al. Guidelines for the Management of Arterial Hypertension. The Task Force for the Management of Arterial Hypertension of the European Society of Hypertension (ESH) and of the European Society of Cardiology(ESC). J Hypertens 2007;25:1105-87.

[12] Nutritional Anaemias. Report of a WHO Scientific Group. WHO Tech Rep Ser 1968;405:1-40.

[13] Pfeiffer E. A short portable mental status questionnaire for the assessment of organic brain deficit in elderly patients. J AmGeriatrSoc 1975;23:433-4

[14] Mahoney FI, Barthel DW. Functional evaluation: the Barthel index. Md State Med J 1965;14:61-5

[15] Rector TS, Kubo SH, Cohn JN. Patients' self-assessment of their congestive heartfailure. Pt 2. Content, reliability, and validity of a new measure, the Minnesota Living with Heart Failure Questionnaire. HeartFail J 1987;3:198-208.

[16] Frazier CG, Alexander KP, Newby LK, Anderson S, Iverson E, Packer $M$ et al.: Associations of gender and etiology with outcomes in heart failure with systolic dysfunction: a pooled analysis of 5 randomized control trials. J. Am. Coll. Cardiol. $2007 ; 49,1450-1458$

[17] Levy D, Larson MG, Vasan RS, Kannel WB, Ho KK: The progression from hypertension to congestive heart failure. JAMA 1996;275, 1557-1562.

[18] Cleland JG, Swedberg K, Follath F, Komajda M, Cohen-Solal A, Aquilar JC et al.; Study Group on Diagnosis of the Working Group on Heart Failure of the European Society of Cardiology: The EuroHeart Failure Survey programme - a survey on the quality of care among patients with heart failure in Europe. Part 1: patient characteristics and diagnosis. Eur. Heart J. 2003, 24, $442-463$

[19] Johnstone D, Limacher M, Rousseau M, Liang CS, Ekelund L, Herman $\mathrm{M}$ et al. Clinical characteristics of patients in studies of left ventricular dysfunction (SOLVD). Am J Cardiol 1992;70:894-900

[20] Masoudi FA, Havranek EP, Smith G, Fish RH, Steiner JC, Ordin DL et al.: Gender, age, and heart failure with preserved left ventricular systolic function. J. Am. Coll. Cardiol. 2003, $41,217-223$

[21] Vasan RS, Larson MG, Benjamin EJ, Evans JC, Reiss CK, Levy D: Congestive heart failure in subjects with normal versus reduced left ventricular ejection fraction: prevalence and mortality in a population-based cohort. J. Am. Coll. Cardiol. 1999, 33, 1948-1955

[22] Yancy CW, Lopatin M, Stevenson LW, De Marco T, Fonarow GC, ADHERE Scientific Advisory Committee and Investigators: Clinical presentation, management, and inhospital outcomes of patients admitted with acute decompensated heart failure with preserved systolic function: a report from the Acute Decompensated Heart Failure National Registry (ADHERE) Database. J. Am. Coll. Cardiol. 2006, 47, 76-84.

[23] Biagi P, Abate L, Alessandri M, Bocchini S, Verdiani V, Pettinà $\mathrm{G}$ et al. Heart failure with preserved systolic function: prevalence and clinical features in a cohort of patients admitted to internal medicine units. The study PRESYF-HF Tuscany. Monaldi Arch Chest Dis 2007; 68: 165-169.

[24] Cirillo M, Laurenzi M, Mancini M, Zanchetti A, Lombardi C, De Santo NG: Low glomerular filtration in the population: prevalence, associated disorders, and awareness.Kidney Int 2006, 70:800-806

[25] Minasa M, Hatzogloua C. Karetsia E, Papaioannou A I, Tanoua K, Tsarouchaa $\mathrm{R}$ et al. COPD prevalence and the differences between newly and previously diagnosed COPD patients in a spirometry program Primary Care Respiratory Journal 2010; 19: 363-370.

[26] Ghali JK, Krause-Steinrauf HJ, Adams KF, Khann SS, Rosembreg JD, Yancy CV et al.: Gender differences in advanced heart failure: insights from the BEST study. J. Am. Coll. Cardiol. 2003; 42, 2128-2134

[27] Simon T, Mary-Krause M, Funck-Brentano C, Jaillon P: Sex differences in the prognosis of congestive heart failure: results from the Cardiac Insufficiency Bisoprolol Study (CIBIS II). Circulation 2001;103, 375-380.

[28] Kenchaiah S, Evans JC, Levy D, Wilson PWF, Benjamin EJ, Larson MG et al.: Obesity and the risk of heart failure. $\mathrm{N}$. Engl. J. Med. 2002; 347, 305-313

[29] Wang J, Sarnola K, Ruotsalainen S, Moilanen L, Lepisto P, Lakso $\mathrm{M}$, et al. The metabolic syndrome predicts incident congestive heart failure: A 20-year follow-up study of elderly Finns. Atherosclerosis 2010; 210: 237 - 242.

[30] Bahrami H, Bluemke DA, Kronmal R, Bertoni AG, LloydJones DM, Shahar E, et al. Novel metabolic risk factors for incident heart failure and their relationship with obesity: The MESA (Multi- Ethnic Study of Atherosclerosis) study. J Am CollCardiol 2008;51: 1775 - 1783.

[31] Ingelsson, E, Sundström, J, Ärnlöv, J, Zethelius, B, Lindt, L Insulin resistance and risk of congestive heart failure. JAMA 2005; 294: 334-40.

[32] Ingelsson E, Arnlov J, Lind L, Sundstrom J. Metabolic syndrome and risk for heart failure in middle-aged men. Heart 2006;92:1409-13.

[33] Biagi P, Nardi R, Mathieu G, Vescovo G, Scanelli G, on behalf of the CONFINE Study Group. Metabolic syndrome and heart failure: Data from the FADOI CONFINE study. It. J. Intern Med 2014;8: 169-175

[34] Rathore SS, Foody JM, Wang Y et al.: Sex, quality of care, and outcomes of elderly patients hospitalized with heart failure: findings from the National Heart Failure Project. Am. Heart J. 2005;149, 121-128 
[35] Lenzen MJ, Rosengren A, Scholte op Reimer WJ, Follath F, Boersma E, Simoons ML et al.: Management of patients with heart failure in clinical practice: differences between men and women. Heart 94, 2008E10

[36] O'Meara E, Clayton T, McEntegart MB, McMurray JJ, Pina L, Granger $\mathrm{CB}$ et al.: Sex differences in clinical characteristics and prognosis in a broad spectrum of patients with heart failure: results of the Candesartan in Heart Failure: Assessment of Reduction in Mortality and Morbidity (CHARM) program. Circulation 2007; 115, 3111-3120

[37] Ghali JK, Pina IL, Gottlieb SS, Deedwania PC, Wikstrand JC: Metoprolol $\mathrm{CR} / \mathrm{XL}$ in female patients with heart failure: analysis of the experience in Metoprolol Extended-Release Randomized Intervention Trial in Heart Failure (MERIT-HF). Circulation 2002, 105, 1585-1591.

[38] MERIT HF study Group.Effect of metoprolol CR/XL in chronic heart failure: Metoprolol $\mathrm{CR} / \mathrm{XL}$ Randomised Intervention Trial in Congestive Heart Failure (MERIT-HF). Lancet 353, 2001-2007 (1999).

[39] Packer M, Fowler MB, Roecker EB, Coats AJG, Katus HA, Krum $\mathrm{H}$ et al.: Effect of carvedilol on the morbidity of patients with severe chronic heart failure: results of the Carvedilol Prospective Randomized Cumulative Survival (COPERNICUS) study. Circulation 2002, 106, 2194-2199.

[40] Flather MD, Yusuf S, Kober L, Pfeffer M, Hall A, Murray G et al: Long-term ACE-inhibitor therapy in patients with heart failure or left-ventricular dysfunction: a systematic overview of data from individual patients. ACE-Inhibitor Myocardial Infarction Collaborative Group. Lancet 2000;355, 1575-1581.

[41] Jong P, Yusuf S, Rousseau MF, Ahn SA, Bangdiwala SI: Effect of enalapril on 12-year survival and life expectancy in patients with left ventricular systolic dysfunction: a follow-up study. Lancet 2003;361, 1843-1848.

[42] Shekelle PG, Rich MW, Morton SC, Atkinson CS, Tu W, Maglione $\mathrm{M}$ et al. Efficacy of angiotensinconverting enzyme inhibitors and beta-blockers in the management of left ventricular systolic dysfunction according to race, gender, and diabetic status: a meta-analysis of major clinical trials. J AmCollCardiol 2003;41:1529-38.

[43] Pitt B, Segal R, Martinez FA, Meurers G, Cowley AJ, Thomas I et al: Randomised trial of losartan versus captopril in patients over 65 with heart failure (Evaluation of Losartan in the Elderly Study, ELITE). Lancet 1997;349, 747-752 .

[44] Hudson M, Rahme E, Behlouli H, Sheppard R, Pilote L: Sex differences in the effectiveness of angiotensin receptor blockers and angiotensin converting enzyme inhibitors in patients with congestive heart failure - a population study. Eur. J. HeartFail. 2007, 9, 602-609.

[45] The Digitalis Investigation Group: The effect of digoxin on mortality and morbidity in patients with heart failure. N. Engl. J. Med. 1997;336, 525-533.

[46] Rathore SS, Wang Y, Krumholz HM: Sex-based differences in the effect of digoxin for the treatment of heart failure. N. Engl. J. Med. 347, 2002; 1403-1411

[47] Ahmed A, Rich MW, Love TE, Lloyd-Jones DM, Aban IB, Colucci WS et al.: Digoxin and reduction in mortality and hospitalization in heart failure: a comprehensive post hoc analysis of the DIG trial. Eur. Heart J. 2006;27, 178-186
[48] Dries DL, Rosenberg YD, Waclaw MA, Domanski MJ. Ejection fraction and risk of thromboembolic events in patients with systolic dysfunction and sinus rhythm: evidence for gender differences in the studies of left ventricular dysfunction trials. J AmCollCardiol 1997;29:1074-80.

[49] Ogilvie IM, Newton N, Welner SA, Cowell W, Lip GY. Underuse of oral anticoagulants in atrial fibrillation: a systematic review Am J Med 2010, 123:638-645.

[50] Stewart AL, Greenfield S, Hays RD, Wells K, Rogers WH, Berry SD et al. Functional status and well-being of patients with chronic conditions. Results from the Medical Outcomes Study. JAMA. 1989;262:907-913

[51] Dracup K, Walden JA, Stevenson LW, Brecht ML. Quality of life in patients with advanced heart failure. J Heart Lung Transplant. 1992;11:273-279.

[52] Hawthorne MH, Hixon ME. Functional status, mood disturbance and quality of life in patients with heart failure. ProgCardiovascNurs. 1994;9:22-32.

[53] Krumholz HM, Butler J, Miller J, Vaccarino V, Williams CS, Mendes de Leon CF et al. Prognostic importance of emotional support for elderly patients hospitalized with heart failure. Circulation. 1998;97:958-964.

[54] Riedinger MS, Dracup KA, Brecht ML, Padilla G, Sarna L, Ganz PA: Quality of life in patients with heart failure: Do gender differences exist? Heart Lung 2001;30: 105-116

[55] Meyer K, Laederach-Hofmann K. Effects of a Comprehensive Rehabilitation Program on Quality of Life in Patients With Chronic Heart FailureProgCardiovascNurs. 2003;18:169-176

[56] Rector T, Kubo SH, Cohn JN. Patients' self-assessment of their congestive heart failure. Part 2: content, reliability and validity of a new measure, The Minnesota Living with Heart Failure Questionnaire. Heart Fail. 1987; 3:198-208

[57] Quittan M, Wiesinger GA, Crevenna R. Cross-cultural adaptation of the Minnesota Living With Heart Failure Questionnaire for German-speaking patients. J RehabilMed. 2001;33:182-186

[58] Zuccalà G, Onder G, Marzetti E, Lo Monaco MR, Cesari M, Cocchi A et al. Use of angiotensin-converting enzyme inhibitors and variations in cognitive performance among patients with heart failure. EurHeart J 2005;26: 226-233

[59] Zuccalà G, Marzetti E, Cesari M, Lo Monaco MR, Antonica L, Cocchi A et al. Correlates of cognitive impairment among patients with heart failure: Results of a multicenter survey. Am J Med 2005;118:496-500

[60] HsichEM, Grau-Sepulveda MV, Hernandez AF, Peterson ED, Schwamm LH, Bhatt DL, et al. Sex differences in inhospital mortality in acute decompensated heart failure with reduced and preservedejection fraction. Am Heart J. 2012;16:430-437.

Members of the CONFINE Study Group (at the time of the study) S Di Rosa, C Cicatello, C Rinollo (Palermo); G Vescovo,

M Muriago, G Dal Pozzolo (Vicenza); D Galasso, S Mazzuca,

C Pintaudi (Catanzaro); A Bonanome (Adria-RO); F Miserocchi,

L Montanari (Ravenna); L Lusiani, G Carra, G Mantineo (Castelfranco Veneto-TV); D Panuccio, E Romboli (Bologna);

G Pettinà, A Armento (Pistoia); P Biagi, S Bocchini, L Abate (Montepulciano-SI); P Bellis (Napoli); M Grandi, C Sacchetti (Sassuolo-MO); M Marchesi, F Egger (Bolzano); MA Iacono, 
G Fazio (Gemona del Friuli-UD); M Cipriani, M Alessandri (Grosseto); G Scanelli (Ferrara); V Manicardi, P Montanari, M Meschi, S Musini (Montecchio Emilia-RE); D Sommariva (Garbagnate Milanese-MI); S Zamboni (Rovigo); G Beltramello, M De Antoni (Bassano del Grappa-VI); L Procopio, E Barcellini, E Buonocore (Menaggio-CO); C Bianco, A Corso, G Barbuto,

R Chessari, M L'Andolina (Tropea-VV); P Lambelet, S Fascetti (Camaiore-LU); G Fera (Monopoli-BA); A Bulfoni,

S De Carli (Udine); F Rollo, S Basso (Acquapendente-VT);

G Musca, O Cuccurullo (San Marco Argentano-CS); G Cioni (Pavullo nel Frignano-MO); C Politi, C Mancini, F Iacovetta (Isernia); E Leccardi, M De Alessi, A Graziano (Casale Monferrato-AL); G Mathieu, A Marandino, M Carosio (Pinerolo-TO); A. D'Angelo (Palermo); A. Napoli, M. Ongari, A Evangelisti (Porretta Terme-BO); D Di Michele, D Parisi (Teramo); L Anastasio, A Arone (Soriano Calabro-VV); A Colli (Lecco); G Chesi, F Dall'Orto (Scandiano-RE); F Colombo (Milano); F Cipollini (Amandola-AP); GA Di Nucci,

A Antonelli, G Attademo, P Pescetelli (Agnone-IS); P Pauletto, M Rattazzi, P Valenti (Treviso); C Castello, S Spinosa

(Genova); A Artom, D Mela, M Uccelli (Pietra Ligure-SV);

B. Madaffari (Reggio Calabria); F. D'Amore (Roma); C. Pascale, A. Bosio, F. Cerrato, G. Epifani (Torino); L. Addis

(Tempio Pausania); E. Paolicelli (Tricarico-MT); M. Vanoli (Merate-LC); M. Campanini, S. Pittau (Novara); F.C. Raimondo, A.M.D. Drago (Salemi-TP); C. Nozzoli (Firenze);
F. Rondoni (Assisi-PG); S. Costantino (Roma); L. Grossi (Novafeltria-PU); A. Belfiore (Bari); C. Passaglia, G. Tintori (Pisa); G. Landini, E. Ubaldi (Cecina-LI); G. Bittolo Bon,

F. Serafini (Mestre-VE); F. Salvati (Guardiagrele-CH);

R. Cavaliere, S. Marengo, C. Norbiato (Torino); G.B. Ambrosio,

A. Nogara (Venezia); S. Contini (Latina); M. Stornello, E. Valvo (Siracusa); P. Parise, A. Procacci (Gubbio-PG); M. Visconti,

S. Lucà, N. Armogida, A Costa (Napoli); R Nardi (Bazzano-BO); C. Carapezzi, V. Ferrari (Carpi-MO); G. Coccia (Roma); Mongiardo(Viterbo); G Lo Pinto, G Antonucci (Genova);

D Ruggiero (Terlizzi-BA); G Vagheggini, A Tafi, S Meini (Volterra-PI); G Mancuso (Lamezia Terme-CZ); A Falco (Popoli-PE); F. Orlandini (La Spezia); M.C. Bertoncelli, A. De Nigris (Borgomanero-NO); LA De Giorgio (La Spezia);

G Pedretti, M Zigliotti (Borgo Val di Taro-PR); G Traisci,

L De Feudis (Pescara); A D'Avanzo, G Vietri (Avellino); GA Rinaldi, Q Lucchesi, MC Bertieri, R Biondi, F Rosatti, C Gigli (Barga-LU); B Biscottini, M Gambacorta, A Boccali, I Bartolini (Todi-PG); G Ioli (Santarcangelo di Romagna-RN); O Garognoli (Città di Castello-PG); AM Comelli (Clusone-BG);

C Di Donato, M Bozzoli (Vignola-MO); C Carpino (Mormanno-CS);R Pastorelli, T Carrabs (Colleferro-RM); G Monti (Saronno-VA); N Acquarone (Genova); P Pancera (Legnago-VR). 